\title{
Public sector economics - introduction to the inaugural issue
}

KATARINA OTT, Ph.D.

DUBRAVKO MIHALJEK, Ph.D.

Editors' introduction

https://doi.org.10.3326/pse.41.1.1

Katarina OTT

Institute of Public Finance, Smičiklasova 21, 10000 Zagreb, Croatia e-mail: kott@ijf.hr

ORCID iD: 0000-0003-2242-4181

Dubravko MIHALJEK

Bank for International Settlements, Centralbahnplatz 2, 4051 Basel, Switzerland e-mail: Dubravko.Mihaljek@bis.org ORCID iD: 0000-0003-4706-9534 
In 2016, the journal Financial Theory and Practice celebrated its 40th anniversary. Born in 1976 under the name Financijska praksa and published in Croatian, the journal came of age in 1995, when it was renamed Financijska teorija i praksa. From 2005, it was published in both Croatian and English, and since 2010, it has appeared only in English, as Financial Theory and Practice. At the ripe old age of forty, the journal is now ready for a new venture - hence the new profile and name, Public Sector Economics; a brand new digital publication platform; and a refreshed Editorial Board.

To launch this inaugural issue, the Institute of Public Finance together with Friedrich Ebert Stiftung organised a conference in Zagreb on 14-15 October 2016. The call for papers invited contributions on the future role and functioning of the public sector, including effective and equitable ways to finance public expenditure, and the potential of public investment to foster growth and development. We received some sixty submissions from around the world, and selected around half of them for the conference programme.

The topics of around two dozen papers that were presented covered a wide range of issues. These included macro fiscal policy, fiscal sustainability and the interplay of fiscal and external stabilisation; the design and impact of tax reforms, including on income distribution; the impact of demographic changes on tax revenues; decentralisation and local government budget openness; the impact of EU institutions and governance on growth and domestic policies; and social protection, education, sport, culture and infrastructure. This first issue of Public Sector Economics contains a selection of speeches and papers from that conference.

\section{A LOOK BACK}

The contents of our journal have evolved in line with the Croatian political and economic context and the extent to which Croatian researchers were integrated in the worldwide academic community. In 1976, when the first issue of Financijska praksa appeared, the global economy was still reeling from the two major shocks of the early $1970 \mathrm{~s}$ - the collapse of the Bretton-Woods system of fixed exchange rates, and the 1973 oil crisis - that profoundly changed the post-war international economic order.

The economy of former Yugoslavia, which naturally formed the backdrop for the new journal, was already at that time closely integrated with and dependent on the economies of Western Europe. It felt the impact of these shocks intensely: the economy was highly dependent on imports of oil, and general government deficits - a term not yet in use - were financed with an inflation tax and, to an important degree, loans from foreign commercial banks to the federal government. The year 1976, when the first issue of Financijska praksa appeared, was in fact a year of one-off good macroeconomic performance. Output expanded by around $6 \%$ in real terms; inflation was brought down to $9 \%$ from over $25 \%$ a year before; the external 
current account was almost in balance; and public finances showed no major imbalances. However, by the end of the 1970s, the Yugoslav economy was fully immersed in high inflation and an external debt crisis. In that respect, Yugoslavia was quite similar to the highly indebted Latin American economies of the 1980s.

Against this backdrop, the journal in its early years focused on technical issues related to unsettled public finances in a highly decentralised tax and public expenditure system of the day. Our readership was spread throughout the former federal state and included members of academia and public servants in the then numerous republics, regions and municipalities.

After the collapse of Yugoslavia and the establishment of the Republic of Croatia, the journal adapted to the new circumstances of the early 1990s, in particular the transition from the socialist to a more market-oriented system. Reflecting the circumstances, papers on a wider variety of topics began to be published. Most were still largely from the field of public sector economics, notably the introduction of market-based tax and expenditure systems, but many also addressed different aspects of transition to a market economy, such as economic growth and development, restructuring of the banking system, and the role of institutions and governance in the economy and public finances. Articles were related, but not limited, to the experience of countries in Central, Eastern and Southeastern Europe (CESEE). With the growing interest of the academic community in transition issues, more and more readers came from international academia and less and less from the domestic public administration.

From the early 2000s on, many papers started to focus on the process of EU integration, which was seen as the next - some even thought the final - stage in the development of transition economies. There was much enthusiasm at the time for the single European market for goods, services, labour and capital, not to mention European monetary integration. The private sector took the lead in economic and financial integration, pouring significant amounts of foreign direct investment and cross-border bank credit to the CESEE region, and helping to bring about the muchneeded modernisation of industry and financial services. Accordingly, many papers examined how far or close different countries were from membership in the EU and EMU, and what European integration meant for the public sector and development of local economies. The authorship of articles and the readership of Financial Theory and Practice expanded further in both geographical and institutional terms, as the interest in the European project expanded. In the past few years, articles related to the global financial crisis have given another boost to this expansion.

\section{AND A LOOK FORWARD}

Forty years of continuous publication is no small feat for a periodical in a field of inquiry as broad as public finance. All-round economic journals are increasingly becoming an endangered species in today's academic publishing landscape, characterised by the blossoming of outlets for highly specialised research. Another 
frequently overlooked feature in that landscape is the growing concentration of academic journals in a handful of global scientific publishers. This has enhanced efficiency in the reviewing and publication processes, as well as dissemination of scientific research. However, we feel that it has also resulted in some loss of variety and original thinking, manifested in shifting academic "fashions" concerning research questions, theoretical and empirical models, data, estimation techniques and robustness tests. Before the global financial crisis, for instance, it would have been very difficult to publish a paper on a sovereign debt crisis in the euro area. Likewise, since the crisis it has become very difficult to defend in published research the benefits of international financial liberalisation.

Being mindful of these trends in academic publishing, we have chosen to remain an independent outlet, and to encourage and publish high-quality research on a broad range of topics within the field of public economics, thereby helping to raise the professional profile of this field of inquiry. Rather than focusing on a narrow set of topics, we seek theoretical, empirical and policy-oriented contributions analysing the role and functioning of the public sector at macroeconomic, sectoral and microeconomic levels, in both advanced and emerging market economies. We also aim to provide a professional forum for the discussion of contemporary public policy issues and actively seek survey papers, appraisals of current policy debates, shorter notes and book reviews.

These aims are reflected in yet another change of the name of the journal, to Public Sector Economics. While our articles are mainly aimed at the international academic community, as in the past we would also like to attract professionals engaged with public administration and public institutions, in both advanced and emerging market economies, international organisations, and various professional associations. Under its new name, the journal is committed to diverse and rigorous scholarship and encourages a writing style understandable to a wide professional audience. The qualities looked for in submissions are, in particular, analytical rigour and creativity. We use a double-blind peer review process, drawing referees from a wide pool of experts and follow the highest ethical standards. The journal is published quarterly. The editorial and production processes, which have been moved to a digital platform, ensure a quick turnaround of submissions and publication of accepted papers.

To encourage the discussion of contemporary public policy issues and to enable gatherings of both academics and professionals, the Institute of Public Finance intends to organise annual conferences on Public Sector Economics, which should serve as an additional source of relevant articles for the journal.

Finally, we would like to welcome the new members of our Editorial Board and thank all the members of previous boards. We would also like to announce that in addition to the long-term Editor, Katarina Ott, the journal now has also a Co-editor, Dubravko Mihaljek. 
This inaugural issue of Public Sector Economics contains a selection of keynote speeches, introductory notes and papers presented at the Institute of Public Finance conference held in Zagreb in October 2016, and a recent book review.

The keynote by Debora Revoltella, Chief Economist of the European Investment Bank (EIB), reviews the causes of weak recovery in investment in Europe since the crisis, and policies needed to restart, particularly, innovation-related investment in intangibles. The EIB is involved in the financing of riskier projects unable to secure market funding, and in adopting, through a guarantee scheme, a junior position with respect to private co-financiers. This is a fine example of how European institutions can help overcome a market failure - the credit constraints facing European young innovative firms - and contribute to better allocation of resources.

Zrinka Živković Matijević, Head of the Research Department of Raiffeisenbank Austria in Croatia, reviews Croatian fiscal policy and how it was affected by the crisis. She emphasises that the sources of sustainable growth are currently missing in Croatia, and can only be created through further structural reforms in the pension, health and educational systems, the removal of administrative barriers, and the creation of an adequate and efficient public administration more appropriate to the small size of the country.

Manica Hauptman, Economic Counsellor and European Semester Officer representing the European Commission in Croatia, provides an update on economic governance in the European Union, its 2017 governance cycle, and the main tools for coordination of economic and fiscal policies of the 28 member states. She highlights a number of features of the European Commission's surveillance mechanisms, and suggests how the European Semester could address not only the economic but also the political and democratic challenges facing the EU.

Zdravko Marić, Minister of Finance of the Republic of Croatia, summarises the economic challenges and opportunities facing the Croatian economy. He outlines the way in which the Government has been addressing structural vulnerabilities by trying to improve fiscal sustainability and economic growth, and at the same time working to reduce government budget deficits and public debt. He sees a permanent reduction of the debt burden and the improvement of credit rating as the key priorities of the Government's current economic policy.

Rilind Kabashi, from the National Bank of the Republic of Macedonia, studies the near and medium-term fiscal multipliers - i.e. the effects of fiscal policy on output and other macroeconomic variables - in EU countries between 1995 and 2012. He finds that expansionary spending shocks have a positive but relatively small effect on output, which is higher in new member states and countries with low public debt and low trade openness. In old member states, by contrast, spending shocks are smaller and typically followed by rising debt levels. 
Martin Beznoska and Tobias Hentze, both from the Cologne Institute for Economic Research (IW), use a microsimulation model to assess the impact of expected demographic changes in Germany on future income tax revenue. Their model suggests that the tax revenue could decrease by $7 \%$ within the next 20 years, since pensioners pay on average lower taxes than employees do, and because population ageing will probably outweigh net immigration. In their view, no more than two election periods will be available to upgrade the tax system in such a way that it can address these challenges of demographic change.

Šime Smolić, from the University of Zagreb, Faculty of Economics and Business, studies the self-assessed health of people aged 50 years and over in Croatia, based on the data from an EU-wide survey of health, ageing and retirement. He finds that females are more likely than males to assess their health as better, and that higher educational level is a statistically significant predictor of higher self-assessed health, when controlling for other variables.

Marijana Bađun, from the Institute of Public Finance, explores in her paper why roughly one quarter of Croatia's retired population receives a pension based on disability. It turns out that, in addition to health and war related factors, inadequate institutional reforms had a strong impact on the number of disability pension beneficiaries, while the granting of disability pensions was often plagued by corruption.

These articles present just the first selection of papers presented at the Conference; several more will appear in subsequent issues of the Journal.

The issue ends - quite appropriately for this journal - with a review of the book on the multi-level finance and the euro crisis edited by Ehtisham Ahmad, Massimo Bordignon and Giorgio Brosio. 